\title{
Community Justice and Juvenile Offender: The Management of an Individual Case with Criminal Slope with Community Involvement
}

\author{
Antonio ludici \\ Department of Philosophy, Sociology, Education and Applied Psychology, University of Padova \\ Annunciata Maiocchi \\ Psychologist, Psychotherapist, Department of Child and Family Protection, \\ Melzo (Milano), Soc.Coop. Dialogica (Milano) \\ Email: antonio.iudici@unipd.it
}

\section{Doi:10.5901/mjss.2014.v5n20p2015}

\begin{abstract}
This work examines how the Italian state follows the international guidelines relating to juvenile justice. Specifically, we consider the decree 448/88, which has some innovative features within the juvenile justice system compared to traditional models of retributive justice and punishment. This paper describes a case study application in reference to the concept of the Restorative Justice Community Oriented applies in Italy, highlighting the practical strategies implemented in the intervention.
\end{abstract}

Keywords: Restorative Justice, Community Justice, Probation, Diversion, Juvenile Justice

\section{Introduction}

This paper aims to describe how the Italian state follows international guidelines, in the area of juvenile justice, particular attention will be placed on decree 448/88. Decree 448/88 represents the application of the Italian model of restorative justice and offers the features of an innovative judicial structure, when compared to traditional models of punitive and retributive justice (Bazemore \& Umbreit, 1995). The aim of the system is to reduce the high reoffending rates when a minor is simply placed in detention (Pullman et al, 2006; Robertson et al, 1998). This paper aims to show how the restorative justice system is applied in Italy, and by referring to Walgrave's studies $(1995,1998,2008)$, concerning the history and assumptions of restorative justice, Winterdyk's research (1997), into how the system is applied and works in practice, and studies into the results obtained from restorative justice and reoffending (Bergseth \& Bouffard, 2007, Pranis, 1998, Bazemore 2007, 2008), highlight both its critical aspects and favourable outcomes. This paper demonstrates that there is a need to develop skills in the community, in order to counter community conditions, such as limited resources, limited educational opportunities, lack of leisure facilities and opportunities, which encourage juvenile delinquency (Li et al., 2007; Sprott, Jenkins \& Doob, 2005; Brown et al., 1997; Cottle et al., 2001; Walker et al., 1996).

\section{International References}

In most jurisdictions, until comparatively recently (and, in some states, even today) minors were judged in the same criminal courts as adults, rather than special juvenile courts and justice systems. At international level, there is a strong concern in the face of the increasingly punitive response of some European States, towards crimes committed by minors, who are often sentenced to imprisonment, without any commitment to rehabilitation. European Council (Council of Europe, 2009) highlights the discrepancy between perceptions of increasing juvenile violence and the statistics, which do not show increases in juvenile delinquency rates. It is necessary remember that, at the international level, a "minor" is a person under the age of 18 years (excepting where the normal age of majority in a state is younger than 18). The most recent definition contained in the Recommendation $\mathrm{cm} / \mathrm{Rec}$. 11 art. 21.1 (Council of Europe, 2008), defines a juvenile offender as "any person under the age of 18 years suspected of having committed, or who has committed, a crime".

Various documents, by European institutions, together with principles set out in international conventions on juvenile justice (discussed below) emphasize the necessity of using diversion programs during criminal proceedings and that detention should only be used as a last resort. The International Convention on the Rights of the Child (United 
Nations General Assembly, 1989) adopted by General Assembly of the United Nations 20 November 1989 Art. 37: clearly states "the arrest, detention and imprisonment of a child shall be used only as a measure of last resort and for the shortest period possible". The same article prohibits capital punishment and life imprisonment, without possibility of release, for juvenile offenders.

There are three documents through which the General Assembly of the United Nations has expressed itself in the field of juvenile justice:

- The Standard Minimum Rules of the United Nations Administration of Juvenile Justice (the Beijing Rules) of 29 November 1985;

- The United Nations Guidelines for the Prevention of Juvenile Delinquency (the Riyadh Guidelines) of 14 December 1990;

- The United Nations Rules for the Protection of Juveniles deprived of their Liberty (Havana Rules) of 14 December 1990.

One of the first contributions was given by the United Nations General Assembly (1985): Resolution 40/33 of 29 November 1985 entitled "Minimum Rules Standard of the United Nations for the Administration of Juvenile Justice" (Beijing rules). The document points out that the main difficulty in finding common guidelines is to reconcile different visions of justice, such as: rehabilitation vs. abandonment, and assistance vs. repression and punishment. The task of the juvenile justice system is to identify what is best for the minor, or the best action for the minor to understand his mistake and at the same time, making reparation to the community, so that he may grow to understand his responsibilities to the community, so that he may grow as a person, to take his proper place within that community. These ideas are not to please idealistic "do- gooders", but to promote the welfare of both the individual and his community. The core of this resolution is the interest of the child. UN Convention Art 40 (United Nations General Assembly, 1989) further affirms the right of the child to receive treatment "that takes into account his age and the need to facilitate his reintegration into society and to get him to play a constructive role in the community".

To do so, the resolution $40 / 33$ poses of the essential principles:

1) The basic principle concerns the child's interests, and places any decision or action only towards these ends.

2) The principle of proportionality, according to which any action towards a minor offender must be proportional to the seriousness of the offense, but must also take into account the personal circumstances of the offender.

3) The protection of the presumption of innocence until proven guilty, which must be guaranteed until further notice.

4) The protection of privacy, because children are easily subject to stigmatization, which implies significant harmful effects. Indeed labelling a person as "delinquent" "pre-delinquent" or "deviant" often helps to reinforce the pattern of undesirable behaviour.

This must also be translated also in practice, for example, into further researching alternative solutions to the judgment of a court. Moreover, it is necessary to involve the minor and the context in which these solutions are used. For example, by encouraging the diversion of health and social services, using the police or informal strategies, such as community-based diversion, especially where the offence is not serious and the school, the family and the other informal social institutions, have reacted, or are reacting, in an appropriate manner. Some measures can be used together, such as: psychological support or assistance, guidance school or work, community work, financial penalties, compensation and restitution, requirements on school attendance or at group activities, requirements of foster care, on life in the community or in other educational settings, and other possible solutions available to the competent authority. The same article 40 (United Nations General Assembly, 1989) states further that States must take measures, whenever it is possible and desirable, for dealing with such children, without resorting to judicial proceedings. It is hoped, therefore, that states adopt diversionary measures into juvenile justice systems to be applied not only to first time offenders or those committing very trivial offences, but in as many cases as possible. In any case, whatever the decision, no young person should be removed from parental authority either wholly or partially, unless there are circumstances which make it necessary to do so. Detention should only be used as a last resort and where it is used, should be for a limited period of time.

A minor deprived of liberty "must be held separate from adults unless the contrary is not considered a preferable solution in the best interests of the child" as stated in art. 37 (United Nations General Assembly, 1989), this indication is reiterated the rule 29 of the Havana Rules that states the principle of separation from adults, unless it is members of the same family or unless the contact with carefully selected adults benefits the young offender (United Nations General Assembly, 1990). This avoids the danger of criminal contamination, or being adversely affected by adult prisoners.

It is emphasized that minors in detention should still enjoy all their rights, with particular attention to their health and safety. During the custody period, authorities must ensure protection and all that is needed to care for the young prisoner, in terms of social welfare, educational, vocational, psychological, and medical care, and must work to facilitate the young 
offender's rehabilitation and re-entry into society, especially in cases of substance abuse, mental illness, or where the minor is found to suffer some kind of trauma, related to the situation. This resolution is chronologically followed by others: the U.N guidelines on prevention (the Riyadh Guidelines), and the United Nations Rules for the Protection of Juveniles Deprived of Liberty (Havana Rules). The United Nations guidelines on the crime prevention of 14 December 1990, state that: "the prevention of delinquency is an essential part to prevent crime in society" (United Nations General Assembly, 1990b, p. 138).

It is therefore essential to have specialized approaches and philosophies aimed at the prevention of delinquency on the basis of laws, processes, institutions, facilities and service networks, "aimed at" reducing the motivation, need, opportunity and conditions for the occurrence of illegal acts (United Nations General Assembly, 1990b).

This is possible, says the UN, engaging children in lawful activities, which are socially useful, and necessary to foster a vision of society as human and empathetic and themselves as active, collaborative and constitutive of society, this would prevent the development of criminogenic attitudes.

Therefore services and community-based programs are necessary, whether family, school, peer, age or belonging to any other organizational reality. Such services and community-based programs become an important means of crime prevention socialization and integration enable children and young people to feel accepted and to live together with others, as participants in their society.

Crime prevention of crime, therefore, coincides initially with social policies that promote the harmonious growth of children from early childhood. Policies and measures and policies implemented should cover a range of opportunities, especially in education, in order to meet the developmental needs of all young people, especially those who require special care.

In reference to the protection of minors held in detention, the United Nations (United Nations General Assembly, 1990b) describes procedures relating to their management: a) administrative matters, such as the processing of files related to the juvenile offender, b) practical aspects, such as the suitability of the physical environment and, in particular, housing, c) aspects of the reintegration of the child into society, such as appropriate education, training and work. This text explicitly states the need to guarantee the rights of the child, such as the right to recreation time, the opportunity for a child to satisfy spiritual needs, health care, both with respect to medical care and in dealing with prisoners with mental health problems. Then there are the rights relating to the contacts with the outside world, through appropriate channels of information and with relatives. It is then stated that disciplinary procedures should instill in the young offender a sense of justice, self-respect and respect for the fundamental rights of every person. Consequently, punishments which may harm the physical or mental health of the child, as well as collective punishment are forbidden. Also multiple penalties for the same disciplinary infraction cannot be used. Particular importance is given to the need to have qualified educators, vocational instructors, counselors, psychiatrists and psychologists, who are required to maintain certain behavior standards: "the staff should carry out its work in a humane, professional, committed, fair and effective manner, at all times, in order to deserve the respect of young inmates and to demonstrate a positive role model" (United Nations General Assembly, 1990b).

\section{The European Standards}

With the promulgation of the UN resolutions on the subject of juvenile justice in the $80 \mathrm{~s}$, has come to determine a change in perspective in Europe and the adoption of what was called the "model of responsibility." This model supports the idea that prevention is preferable to repression and that the use of the traditional justice system must be kept to a minimum. By establishing new systems of justice, in other areas, such as social welfare, which treats potentially criminogenic situations, thus limiting punitive state intervention and reducing the deprivation of liberty to exceptional cases. All this contributes to a more agile and diversified criminal law response, adaptable to both the measure of the seriousness of the offence and the circumstances of the child's life.

For this to be feasible, it is necessary to train all those professionals working in this process, in a specialized way. Juvenile delinquency is caused by complicated social phenomena in Europe, which is confirmed by the opinion submitted by the Economic and Social Committee on "The prevention and treatment of child delinquency and the role of juvenile justice in the European Union ".

For the Com Ec. European Soc (Council of Europe, 2010) is necessary "to outline a common strategy to combat juvenile delinquency, not only because it concerns an important part of the community, children, and especially children, who belong to communities at risk of social exclusion, but also, because they prevent and intervene on young offenders, means the prevention of crime of tomorrow".

According to statistics obtained by comparing data from different EU states, juvenile delinquency accounts for $15 \%$ 
of all criminal acts, , but it should be noted that crime predominantly affects young people and there is no available data. Perhaps the effects of these actions do not come to the supervisory authorities' attention, either because they are less serious, or because victims are also young and/or less inclined to go to the authorities.

It is also a fact that in European countries there is a widespread perception that juvenile delinquency is increasing and that the severity of the crimes committed by young people is also increasing. Given the issue's importance concrete actions need to be taken based on three forms of action: crime prevention, punitive-educational measures, and integration and social reintegration of children and young offenders.

The document contains a summary of the main causes of juvenile delinquency focusing more on the economic and socio-environmental on which the Union can act.

1) Membership in broken homes; (families unstructured)

2) socio-economic marginalization and poverty;

3) absenteeism and school failure;

4) lack of work;

5) transmission of images and violent behavior through mass media;

6) consumption of drugs and alcohol;

7) for the previous factors, in combination or independently of them, there may be disturbances of personality and behavior;

Again, as in the UN resolutions, it is believed that the road to the successful resolution of the phenomenon is devise strategies, which combine measures of prevention, intervention and suppression, in particular, the prevention/intervention strategies should be aimed at socializing and integrating all children and young people, especially in the family, the community, peer groups, schools, vocational training and the labor market. At the European level, the Council (2009) adopted the European Rules for juvenile offenders, the recipients of sanctions or measures, which aim to ensure the rights and safety of young offenders, subject to sanctions or measures. Art. 5 emphasized that the penalties imposed should be based on the child's interests, with particular reference to the principle of proportionality (i.e. the commensurate punishment based on the seriousness of the offense, taking into account the age of the child, his psychophysical development, ability and personal circumstances), and Art. 9 the minimum intervention necessary (to ensure that social ties are protected and preserved).

The Council of Europe has adopted a series of recommendations which have as their object the delinquency and juvenile justice:

- Recommendation No. R (87) 20 on social reactions to juvenile delinquency;

- Recommendation No. R (88) 6 on social reactions to juvenile delinquency among young people coming from migrant families;

- Recommendation No. R (99) 19 on the promotion of both public and private mediation by individual states;

- Recommendation No. R (2000) 20 on the role of early psychosocial intervention in the prevention of criminal behavior;

- Recommendation No. R (2003) 20 concerning new ways of dealing with juvenile delinquency, juvenile justice within which is defined as a component of a broader strategy for the prevention of juvenile delinquency, which takes into account the overall context: the family, the school, the neighborhood, the parent group in which the delinquency occurs (art. 2);

- In Recommendation No. R (2004) 10 speaks of the protection of human rights and dignity of individuals with mental disorders, which must be able to exercise their civil and political rights (Article 4) and be helped in the least restrictive possible;

- Recommendation No. R (2005) 5 on the rights of children in institutions of custody;

- Recommendation No. R (2006) 2 on the European Prison Rules.

The various documents cited show special attention to the child's interests, which must always be safeguarded, and the use of alternative measures (so-called diversion) to detention, wherever possible, to divert young people away from criminal behavior and influences, rather than permanently criminalizing them for silly mistakes.

\section{The New Italian Code of Child Criminal Procedure, the Decree 448/88}

In Italy, international normative references have been acknowledged and the country developed the new code of child criminal procedure child (Presidential Decree 09/22/88 n. 448), with the aim of reducing the numbers of juvenile offenders held in detention. The code emphasizes the fact that to keep children safe from the risk of delinquency it is necessary to 
adopt strategies to prevent social exclusion, which need the participation of family, society and institutions, in order to avoid or reduce judicial interventions. The code calibrates 'penal intervention on the needs of young offenders, taking account of the life of the offender, and follow the principle of proportionality. Juvenile offenders rights are secured, they have the right to be presumed innocent until proven guilty, the right to the presence of a parent or guardian during questioning, the right to notice of claims, and the rights to confrontation and cross-examination of the evidence, the right to silence, the right to appeal , the right to privacy and of course to be represented by a lawyer. The decree also paid particular attention to ensuring that the child understands the pre-trial procedures, the conduct of pre-trial procedures, and the trial itself. This is implicit in the requirement for the notification of arrest of the child to the parents or guardians, as soon as possible. With regard to treatment in prison, whose aim is to help young people to play a constructive role in society, there are specific provisions for minors and the code prohibits the mingling of children and adults in the same institution. The increasing use of probation to which is joined by the support of dedicated probation officer to each offender and the various possible therapeutic communities. 25 years after its application, the decree 448/88 is innovative in that the proposed organizational structure of the penal system triggers the practice of probation, diversion and functional social reintegration.

\subsection{Decree 448 like a new penal system architecture: restorative justice}

Early in of Presidential Decree 448/88, paragraph 2 of Art.1 there is a detectable change from the past, in that the child is central in the process. In fact, the judge must ensure that the child defendant understands the meaning and content of the court activities, which are taking place in his presence, as well as giving ethical reasons for social decisions made concerning the child. The child's participation is of paramount importance, therefore, throughout the process from its initial stages remaining an essential element, because for the start of any education or reparative action it is necessary for the child to participate in every minute, including prescribed' meetings with the judge.

Art. 2 are indicated judicial bodies in this field:

a. the Public Prosecutor at the Juvenile Court;

b. the judge for preliminary investigations at the Juvenile Court;

c. the juvenile court;

d. the Attorney General at the Court of Appeal;

e. the section of the court of appeal for minors;

f. the supervising judge for minors.

To which is added, art. 5, the establishment of specialized sections of the judicial police for minors where the staff must be "endowed with specific skills and competencies."

Art. 9 of Decree 22/09/88 n. 448 is particularly worthy of interest where, in paragraph 1, states that "the public prosecutor and the judge must learn the conditions, personal resources, family, of a minor and the social and environment impact of his actions, in order to ascertain the eligibility and the degree of responsibility, to evaluate the social relevance as well as the appropriate criminal measures and adopt other methods before deciding how to proceed'. Children's lives and conditions are as important as the crime of which they are accused.'

This article is based Art. 3 of the CRC (United Nations General Assembly, 1989), which imposes the principle of the best interests of the child, and the Beijing Rules (United Nations General Assembly, 1985), in particular Rule 5, which emphasizes that "the juvenile justice system must have as its objective the protection of the young and to ensure that the action taken against the young person is proportional to the circumstances of the offence and its author and Rule 17 (United Nations General Assembly, 1985), which set out guiding principles for the trial and judgment. It states that a) the decision must always be proportionate, not only to the circumstances and gravity of the offense, but also to the conditions and needs of the person who has transgressed, as well as the needs of society, b) restrictions on the personal liberty of the child shall be taken only after careful consideration and shall be limited to the minimum necessary, $c$ ) the deprivation of individual liberty is applied if a minor is found guilty of a crime of violence against another person or a relapse, and if there is no other suitable solution d) the protection of the child must be the determining criterion in the evaluation of his case".

Regarding the protection of the child, Article 12 cites "the emotional and psychological assistance to the accused minor is ensured at every stage and level of the proceedings, the presence of parents or other suitable person" and not just the technical help from the defender may help to formulate an adequate defence plan (pursuant to art. 11, based on the provisions of art. 97 of the code of Criminal Procedure), but also to that of the parent and services. Art. 6 states that "in every state and stage of the proceedings the court shall use juvenile justice administration services. Also uses the services set up by the local authorities", and these, interposed between the procedural requirements and the educational 
needs of the child, can play a mediating role.

The protection of the child is expressed also by art. 13 which prohibits the publication and dissemination "of information or images, which will allow the identification of the child, however, involved in the process."

In the first few items we can detect one of the pillars of the new legislation, namely the importance of cooperation between the various parties involved in a criminal trial. The minor, the family or other person exercising parental authority, the defender, the local social services, those in the juvenile justice and judicial authorities are all involved in order to emphasize the "circularity" of actions and decisions in the process.

Chapter II of this Decree, which contains the "measures on personal freedom", contains within it a section on precautionary measures (Articles. Ranging from 19 to 23), designed to meet the "'need not to interrupt the educational processes in place" (Article 19).

Articles 20 (prescriptions) and 21 (stay at home), specify how the judge, considering the child, his family and his context, may intervene to stop the criminal behavior. The first states that "the court, after hearing child's parent or guardian, may give the minor specific requirements concerning study, work or other educational activities", while the second Article states that the judge may order that the child "stay at the family home or other private residence". Paragraph 2 of Art 21 states that the judge can "allow the minor to move away from the building in relation to study or work requirements or for other activities useful for his education."

Articles 22:23 provide for more restrictive sanctions', in particular Art. 22 provides for placement in a community home and Art. 23 provides for pre-trial detention.

It should be noted, however, also in Art. 22 the centrality covered by the rehabilitative purpose of the measure, as it is indicated that the court may impose "any specific requirements concerning study or work or other activities to his [the child's] education."

Such penalties may also be applied after the judgment in place of detention "taking into account the child's personality and needs of work or study, as well as the minor's family, social and environmental conditions" (art. 30). One thing to note, that involves all the precautionary measures mentioned above, is contained in paragraph 3 of Art.19, which states that "when there is disposed a precautionary measure, the court entrusts the accused to the administration services of the juvenile justice system, who carry out activities to support and control him, in collaboration with the services set up by the local authorities." This point is a partial overlap with the custody of the child to the services provided in the case of probation, which will be discussed later (section 28). In both cases, the services are responsible for planning and managing a complex care and control package specific to the particular minor to whom it is addressed.

The innovative capacity of the Presidential Decree is also expressed in art. 27 (following the judgment of non-suit for irrelevance of the fact) in that it provides an opportunity for the re-education of the child in the preliminary investigation stage, since it provides a comparison between the judge, the lower the power operator, as well as the hearing of the victim. The judgment of non-suit may be imposed on the basis of the "tenuous nature of the offence and occasional behavior" and also in the event that "the further course of the proceedings affects the educational needs of the child." In this way, the emphasis is on the conditions of the child investigated rather than on predetermined criteria and objective.

\subsection{Probation}

While in some states, the justice apparatus abstains completely from any form of intervention (of implementing diversion programs such as, for example, family conferencing, the work of the police force), in Italy, there is the institution of probation only in the pre-trial stage. Italy, although it has distinguished itself for the changes introduced with Presidential Decree 448/88, has not implemented a parallel innovation in prison treatment. In this way, there is a clear inconsistency between the trial stage and the executive. The same punishment, which should be used only as a last resort, becomes not only ineffective, but may even be detrimental to the health and development of the child. Perhaps this lack is due to the requirement in art.112 of the Italian Constitution, which requires a mandatory penalty for certain crimes.

Article 28 of Decree 22/09/88 n. 448 provides for the suspension of the process and the testing of the child, "the judge, after hearing the parties, may issue an order for the process when it feels the need to assess the personality of the child on the outcome of the test" in paragraph 2 of same article states that with this measure, "the court entrusts the minor to juvenile services for the conduct of the administration of justice, in collaboration with local services, the appropriate observation activities, treatment and support". In case of success, it has resulted in the declaration of extinction of the offense, according to the provisions of Art. 29 ("after a period of suspension, the judge sets a new hearing, in which he states that a judgment extinguished the offense if, taking into account the behavior of the child and the personality assessment, where the judge believes that the test has given a positive result"). This legal institution, which acts primarily in a rehabilitative and restorative manner, should make changes in the child's way of life towards the 
child's greater empowerment and the context in which it is inserted. To prevail on the punitive aspect is, therefore, the rehabilitative function, in line with the instructions, in Art. 27 of the Italian Constitution, any penalties imposed on the defendant, "must aim at the rehabilitation of the offender." In this sense, in probation the "object of the process is not longer the criminal act, but the person" and his re-education enters fully into the program. It is also the only available tool to ensure that the offender confronts his offending behavior and understands the wrong that he has done his victim.

\section{Restorative Justice}

Increasingly the world is talking about restorative justice, i.e. the paradigm of justice that involves the victim, the offender and the community, in searching for solutions to the conflict caused by the offence, in order to promote the repair of the damage, reconciliation between the parties and the strengthening of the sense of collective security. The term "restorative justice can mean a process in which all stakeholders of a particular offence come together to resolve collectively how to deal with the consequences of the offence itself and the implications for the future that may result from the commission of this" (McGarrell, 2001; Cormier, 2002; Marshall, 1999). This idea summarizes in a formula the two basic aspects of restorative justice: 1 ) the search for a common solution to the conflict - that is processed by the offender and the victim together, if possible, with the participation of the community - and 2) the promotion of an active responsibility by the author of the crime, that is not mere 'atonement' for the evil, but an effective repair of the damage caused. "This approach differs from the logic of punishment, in which interest is directed mainly to the sanction of the subject (Braithwaite, 2002; Goldson, 2009a; Muncie, 2008). In fact, the restorative model defines the crime as a conflict, which causes the breakdown of symbolically shared social expectations. The crime is not only viewed as an offence committed against society, or as a behavior that undermines the established order, and that requires a sentence to be served, but as inherently harmful and offensive conduct that may cause, in the victims, privations, sufferings, pain and even death, and that requires, mainly on the offender's part, the activation of forms of repair of the damage caused (Umbreit, 1995; Bazemore \& Umbreit, 2001).

The new approach changes the object on which lies the interest, which does not include either the offence or the offender's figure, but the focus is on the consequences of the offence, namely the presence of damage caused by the clash between different intentions; also changes the purpose, which is to create the conditions so that the offence can be adequately repaired, helping the victim to find a solution to the problems posed by the offence (Miers, 2001). This is achieved through a process of constructive accountability of the offender about the consequences of his criminal conduct. The new reparative focus wants to bring the victim of the crime at the centre of the penal system, relegating the state to the role of the secondary victim, who enters the process only when its interests have been directly harmed (Walgrave, 2008). The repair does not counterbalance the harm caused by the offence with affirmative action, but its significance is far more complex than mere compensation. The reparative justice model, considers the victim as the main protagonist. "Restorative justice does not want to be an alternative to that compensation, represented by the penal code, but tries to integrate them overcoming the limits" (De Leo \& Patrizi, 2002, p. 67). This "new" model is much more than the simple application of a technique for dealing with conflicts. The production process of socialization can regenerate links between people and provide more opportunities to share and deal with problematic situations, thus regenerating the connective tissue that binds the conflicting to their living environment (Myers, 2008). Starting from the exploration of the social dynamics around the existing conflict, it is possible that the repair "binds" all members of society involved in the conflict. In this sense, the repair is therefore placed in the "de-jurisdiction" and "de-legalization" of the conflict, which moves the lens from the resolution of the conflict into the management of the same, with the involvement of all institutions and parties according to their means (Iudici, Vallorani \& Antonello, 2013).

\section{Restorative Justice Orientated on the Community}

The restorative model can be configured from the ties present in a given community. When the offence is understood as a rupture of social ties in a given community, it refers to the concept of "community justice". The term refers to an idea of justice based on the effects that the crime and the crime have on community life. This interest involves different approaches (Boland, 1998; Goldstein, 1990; Bennett, 1998; Rottman 1996; Bazemore, 1998; Karp \& Clear, 2000; Karp \& Breslin, 2001), united by the idea according to which the community is considered:

- As a victim or damaged, so the attention is focused on the ownership of the legal interest protected by the criminal law provisions and the quantification of the damage;

- As a recipient of the repair and strengthening of the sense of collective security;

- As a social actor of the repair pathway of the offence arising out of a tort 
Restorative justice and community thus appear indissolubly connected. Restorative justice, according to this perspective, is assigned the task of strengthening the social ties and calling each party to a greater sense of "community". "Community justice" can be identified through five conceptual elements: 1) Community justice applies to the districts, the implicit and explicit rules that characterize the context of the neighborhood, and the meanings, values and the ties present in it. 2) Restorative justice is recognized in problem solving, that is in understanding, public safety or crime as a problem to be solved. In this sense, the concern shifts from strategies to identify solutions to the challenges and needs identified by those strategies (Taylor \& Harrell 1996; Kelling, 1992; Sherman et al., 1997), 3) Community justice is a decentralization of authority, namely by setting the interest in respect of a responsibility that is not a centralized hierarchy to a central power, but is displaced through objectives, procedures and duties assigned to the community itself. Therefore, it implies that there are roles assigned to the management of local public good (Corbett, Fitzgerald \& Jordan 1996), 4) Community justice is an opportunity for the promotion of community life, in which the emphasis is on how you develop the ability of community management in difficult situations, regardless of the outcome of the legal action (Bursik \& Grasmick 1993). Intervention through justice is not just a private matter or individual, but it can become an opportunity for community sharing (Sampson, Raudenbush, \& Earls, 1997; Kelling \& Coles, 1996; Boland, 1998; Branom, 2013), 5) Community justice is the involvement of citizens in the process of justice, which arises as a fundamental citizens' participation, direct or indirect, in promoting the expression of a justice almost co-constructed by means of the various roles involved: from the common people, schools, civil organizations to the institutions of utilities and ecclesiastical bodies (Karp \& Clear, 2002).

\section{The Management of an Individual Case with the Involvement of the Community}

\subsection{Description of the situation}

The frame into which fits the situation presented below is that of a Local Service of Protection of Minors, service municipal delegate and the management of the situations juvenile offenders residing in the territory.

It describes the situation of a minor who at age 15 has been charged with the crime of "possession and trafficking of drugs", as he was stopped by the police and found in possession of a quantity of cannabis, greater than the amount allowed for personal use.

Following the arrest by the Police the boy was taken to the Reception Centre at "Beccaria" juvenile prison in Milan, where he was held for one night. The Reception Centre is a place, identified by the decree, in which the minor can remain for up to 72 hours and which is designed to avoid holding arrested minors in jail, even for a few hours.

In conjunction with the firm and the subsequent validation of the offense, according to the procedures provided for in Decree 448, the minor is discharged from the CPA (Reception Center) with a measure that prescribes a series of actions, including through cooperation with local social services, for participation in a project that involves psychological support and educational activities for his benefit.

The child protection service "Minors and Families", in the roles of the social worker and consultant psychologist meet the minor at that event and, in the usual manner of handling young offenders, plan with the child and his family steps for the collection of useful elements under the definition of an intervention project.

Here are the stages of the procedure:

1. An interview with the child and his parents, aimed at the presentation of the service

2. A path of 3 interviews with the child and 2 interviews with the parents is organized, with the aim of gathering the elements into which you put the episode of the crime in context.

3. Analysis is made of the positions of the child and that of his parents: the story is told in a different way by both parents, who separated when the child was 4 years old. A. and his older brother are legally placed with the mother. Over time, contact with father became irregular at the time of the contact with the Minors and Family Service; A. had dropped out of school during the 1st year of secondary school in 2nd grade.

The mother describes A. as a child who has always been "problematic". She said that since kindergarten A. has presented speech problems and has been subjected to evaluations and therapies aimed at the "normalization" of the problem. This approach has meant that A. would address the school curriculum as do as little as it takes to get by and that means trouble disappointing, the mother's original expectations for him. The "problem child" label, on the one hand brought his mother to the continuous interventions of Specialists aimed at 'Finding The Solution', this put the mother and child in the same position of not finding self-management strategies of the child, because he was a "problem" needing solving by experts. These interactive modes have meant that the demands would increase exponentially with the child's age, to become unmanageable in the time period in which the incident took offense. This episode is configured in the 
mother's eyes as the pinnacle of disappointment and confirmation of that her son was "unmanageable" and "problematic". She also observed that her son, even in the face of the gravity of the situation on the episode of crime, tended to minimize what happened and was not prepared to help.

A's father disputes the mother's description of $A$. and openly criticizes his school education. Yet $A$. is deemed competent by his teachers, having a passion for engines and many practical and manual skills, that will help him in finding a job' Father abnegates responsibility for the whole situation, and what occurred, mainly to his ex-wife. He says he has no say in the matter, and that $A^{\prime}$ mother is too permissive towards him. He argues that his methods, unlike the mother's, give very clear limits to his demands. A., for this reason, prefers to live with his mother and A's father visited less. Faced with this preference of the child, the father passively accepts it, he takes no responsibility, to identify strategies for the management of his son, neither in conjunction with his ex-wife, nor individually.

A. presents himself to the service, adhering to his mother's description of him. He argues that the Police have overreacted to the facts of the incident. His first position was that he was only prepared to observe the prescriptions given by the judge, stating that he was not willing to do anything more than that. He describes himself as "someone who has always messed up" - "and who is not so smart." He reports that he has constant clashes with his mother, and says that he does not have a close relationship because "he is too old-fashioned".

The analysis of voices within the community, which the social worker found informally by talking to some of A's acquaintances, (police and various ordinary people), said that his behavior is caused by him keeping bad company.

\subsection{Description of the intervention}

Starting from the analysis of the elements, described herein, and in the application of theoretical references, according to which action can be taken to counter the career biography of a deviant, we proceeded through the definition of an intervention project, within the legal framework of probation.

Starting from an analysis of the configuration of the interactions in which $A$. was inserted it was assessed that the incident of crime would be a critical point A's biographical track, meaning the critical point from which you can generate different directions of the trace development. The offence could have been an event to confirm the labeling process, already in progress, by increasing the risk of a deviant career, or an opportunity to develop management skills of the event.

In order to promote a biographical turning point in the track, which until then had been built through the interactions of the various actors, we proceeded as follows:

Prescription of the judge in relation to psychological support. Inside the frame of the provisions providing for psychological support, and in view of the fact that A. presented himself as the executor of the requirements, you activate a route with the consultant psychologist aims to bring out skills and areas of interest, on which to base project proposals, which can be shared with the child and his family.

Using the resources attributed to the boy, by himself, and by his mother and father. In the face of the mother's declaration that she found it "impossible" to continue to manage the child, all agreed to the transfer of A. to his father who helped a) to enhance the role of worker A., b) offering opportunities to work in small maintenance tasks, c) as well as the management of the child's everyday life in a more structured way.

Shared goals with the minor: Based on the fact that it has been shared with A. giving him the opportunity to embark on a path that would help him in entering the world of work and relying on his skills that had already been expressed in certain areas of employment (agriculture, mechanical).

Identify strategies. A. was added to a local project in which a group of teenagers, accompanied by a teacher, could experiment with different types of laboratory activities.

In addition to the enhancement of skills already expressed through this work it was possible to build occasions when A. could have very different diverse roles his usual activities within a peer group, involving them in disruptive behavior to the point that the group became "impossible" to sustain (construction activities of a video).

The work of the network: The educators of the project shared with the psychologist and social worker work goals, the ongoing monitoring of the different phases of the intervention. In particular, it has worked: a) to change the former model of A. being considered by both himself and others as a "non-intelligent" person, and the labelling of his methods, and $b$ ) through ongoing consultancy support to $A$., which was aimed at highlighting the skills that were gradually brought into play by him.

The job description of the trial court: The experience described has also led to a positive evaluation by the court, which was presented the details of the route taken. 
The creation of new community experiences: From this experience, it was possible to generate a request by $\mathrm{A}$. to be allowed to participate, with a group of other boys, in an activity involving the management of allotment gardens. This activity, within the local context, is one of the initiatives of active citizenship and cooperation (Majee \& Hoyt, 2011), which contribute to the common good, in this case a plot of public land, which would otherwise be run through means involving a cost to the community.

The definition of a formal assignment: Following the path taken, the court case ended with a positive opinion by the judge and ultimately led to the child's exit from the process. At the same time, A. was given the position of head of the garden, which involved functions of coordination and management of the other people involved.

\section{Discussion and Conclusion}

The analysis of the process activated to manage the situation presented shows that the incident of crime has represented in the biographical journey of the child to a chance that promoted skills useful not only to counter the risk of deviance detected at the time the offense was committed, but also to support an activity of active citizenship.

This is made possible by close cooperation between the competent court, social services, reference and associations and social cooperatives within his community. The normative reference, within which everything is done, is that of the Decree 448/88, the articles of which allow one to intervene in a transformative way in terms of the child's reality, especially in prompting the child to repair the harm he did. A fundamental aspect, but less known, it has turned out to share a conceptual and theoretical perspective, which combined social worker, psychologist and the educators of local projects. For example, the sharing of strategies to avoid labelling implies adherence to some specific conceptualizations (Winterdyk, 1997). We believe that a weak point of the decree is not to recognize problems in the sharing of theoretical and methodological references between the various roles involved in the project (Walgrave, 2008). From this we can highlight that the law, while providing the basis for work aimed at the child's social rehabilitation, does not share the same conceptual and experiential paths between, and with the various professionals involved (Baldry, 1998; Daly, 2003; Philippi, Cocozza \& DePrato, 2013). This problem can be overcome by the concept of decentralization and local areas owning their community justice, in which the offence is taken over by local facilities within the area. In this case the social worker and the psychologist of the Minor and Family Service and operators of the various projects in the area (Latimer \& Kleinknecht, 2000). Therefore, an ongoing collaboration between local operators can provide for the sharing of intentions, approaches and methodologies to intervene in a consistent manner in the offender's behavior and life (McDonald \& Moore, 2001).

\section{References}

Abramson, B. (2000). Juvenile Justice: The 'Unwanted Child' of State Responsibilities. An Analysis of the Concluding Observations of the UN Committee on the Rights of the Child, in Regard to Juvenile Justice from 1993 to 2000. International Network on Juvenile Justice/Defence for Children International, Brussels.

Abramson, B.(2006). Juvenile justice: the unwanted child. In: Jensen, E., Jepsen, J. (Eds.), Juvenile Law Violators, Human Rights and the Development of New Juvenile Justice Systems. Hart, Oxford.

Baldry, A.C. (1998). Victim-offender mediation in the Italian Juvenile Justice System: The role of the Social worker. Br J Soc Work, 28 (5), 729-744.

Bazemore, G. (2000). Community justice and a vision of collective efficacy: The case of restorative conferencing. In J. Horney (Ed.), Criminal justice 2000. Policies, processes, and decisions of the criminal justice system, Vol. 3 (NCJ 182410, pp. 225-297). Washington, DC: U.S. Department of Justice, National Institute of Justice.

Bazemore, G. (2007). The Expansion of Punishment and the Shrinkage of Justice: the Need for a New Vision, Social Research, 74(2): 651-663;

Bazemore, G., \& Umbreit, M. (2001). A comparison of four restorative conferencing models (Juvenile Justice Bulletin). Washington, DC: U.S. Department of Justice, Office of Juvenile Justice and Delinquency Prevention.

Bazemore, G. (2008). Restorative Justice: Theory, Practice And Evidence. Forthcoming in 21st Century Criminology: A Reference Handbook. Sage Publications.

Bazemore, G. (1998). The "community" in community justice: Issues, themes, and questions for the new neighborhood sanctioning models. In Community justice: An emerging field, edited by David R. Karp. Lanham, Maryland: Rowman \& Littlefield.

Bennett, S. F. (1998). Community organizations and crime. In Community justice: An emerging field, edited by David R. Karp. Lanham, Maryland: Rowman \& Littlefield.

Bergseth, K. J., Bouffard J. A. (2012). Examining the Effectiveness of a Restorative Justice Program for Various Types of Juvenile Offenders. International Journal of Offender Therapy and Comparative Criminology, July 18, 2012.

Boland, B. (1998). Community prosecution: Portland's experience. In Community justice: An emerging field, edited by David R. Karp. 
Lanham, Maryland: Rowman \& Littlefield.

Braithwaite, J. (2002). Restorative justice and responsive regulation. New York: Oxford University Press.

Braithwaite, J., (2003). Restorative justice and a better future. In: McLaughlin, E., Fergusson, R., Hughes,

G., Westmarland, L. (Eds.), Restorative Justice: Critical Issues. Sage in association with the Open University, London.

Branom, C. (2013). Community-Based Participatory Research as a Social Work Research and Intervention Approach. Journal of Community Practice, Vol. 20, Issue 3, 260-273.

Brown, T. L., Swenson, C. C., Cunningham, P. B., Henggeler, S.W., Schoenwald, S. K., \& Rowland, M. D.

(1997). Multisystemic treatment of violent and chronic juvenile offenders: Bridging the gap between research and practice. Administration and Policy in Mental Health, 25, 221-238.

Bursik, Robert J., and Harold G. Grasmick. (1993). Neighborhoods and crime: The dimensions of effective community control. New York: Lexington Books.

Cohen, S. (1985). Visions of Social Control. Cambridge: Polity.

Corbett, Ronald P., Bernard L. Fitzgerald, and James Jordan (1996). Operation Night Light: An emerging model for police-probation partnership. In Invitation to change: Better government competition on public safety, edited by L. Brown and K. Ciffolillo. Boston: Pioneer Institute for Public Policy Research.

Cormier, R. (2002). Restorative justice: Directions and principles. Ottawa, Ontario: Public Works and Government Services Canada.

Cottle, C. C., Lee, R., \& Heilbrun, K. (2001). The prediction of criminal recidivism in juveniles: A meta-analysis. Criminal Justice and Behavior, 28, 367-394.

Council of Europe (2008). Recommendation CM/Rec(2008/11) of the Committee of Ministers to member states on the European Rules for juvenile offenders subject to sanctions or measures. Council of Europe Publishing, Strasbourg.

Council of Europe (2009). European Rules for Juvenile Offenders Subject to Sanctions or Measures. Council of Europe Publishing, Strasbourg.

Council of Europe (2010). Guidelines of the Committee of Ministers of the Council of Europe on Child Friendly Justice, (Adopted by the Committee of Ministers on 17 November 2010 at the 1098th Meeting of the Ministers' Deputies). Council of Europe, Strasbourg.

Cunneen, C. (2010). The limitations of restorative justice. In: Cunneen, C., Hoyle, C. (Eds.), Debating Restorative Justice. Hart, Oxford.

Daly, K. (2002). Restorative justice: the real story. Punishment and Society, 4 (1), 55-79.

Daly, K. (2003). Making Variation a Virtue: Evaluating the Potential and Limits of Restorative Justice, in Weitekamp, E.G.M. and Kerner, H. J. (eds.) Restorative Justice in Context: International Practices and Directions. Cullompton, Devon: Willan Publishing.

Defence for Children International (2007). From Legislation to Action? Trends in Juvenile Justice Systems across 15 Countries. Geneva: Defence for Children International.

De Leo, G., \& Patrizi, P. (2002). Psicologia Giuridica. Bologna: II Mulino.

Garland, D. (2001). The Culture of Control. Oxford University Press, Oxford.

Gatti, U., \& Verde, A. (2002). In Comparative Juvenile Justice : An overview of Italy in Winterdyk J. Juvenile Justice System: international perspectives. Canadian Scholars Press.

Goldstein, H. (1990). Problem-oriented policing. New York: McGraw-Hill

Goldson, B. (2009a). Child incarceration: institutional abuse, the violent state and the politics of impunity. In: Scraton, P.,McCulloch, J. (Eds.), The Violence of Incarceration. Routledge, Abingdon.

Goldson, B. (2009b). "Difficult to understand or defend": a reasoned case for raising the age of criminal responsibility. The Howard Journal of Criminal Justice 48 (5), 514-521.

Goldson, B. (2011). Time for a fresh start, but is this it? a critical assessment of the report of the Independent Commission on youth crime and antisocial behaviour. Youth Justice: An International Journal 11 (1), 1-25.

Goldson, B., \& Hughes, G. (2010). Sociological criminology and youth justice: comparative policy analysis and academic intervention. Criminology and Criminal Justice 10 (2), 211-230.

Harris-Short, S. (2003). International human rights law: imperialist, inept and ineffective? Cultural relativism and the UN convention on the rights of the child. Human Rights Quarterly 25 (1), 130-181.

Iudici, A., Vallorani, M., \& Antonello, A. (2013). Innovative Law Old Services: Application and Limitations in the Application of Restorative Justice in Italy: Description and Analysis of a Case Study. International Journal of Innovation and Applied Studies, vol. 4, no. 1, pp. 43-51.

Karp D.R., \& Clear, T. R. (2000). Community justice: a conceptual framework. in Boundary changes in criminal justice organizations. Washington D.C.,U.S. Department Of Justice, National Istitute of Justice.

Karp, D. R., \& Clear, T. R. (Eds.). (2002). What Is Community Justice? Case Studies Of Restorative Justice And Community Supervision. Thousand Oaks, Ca: Sage.

Karp, D.\& Breslin, B. (2001). Restorative Justice In School Communities. Youth \& Society 33:2 (December 2001): $249-272$.

Kathleen J., Bergseth A., Jeffrey A., \& Bouffard B. (2007). The long-term impact of restorative justice programming for juvenile offenders. Journal of Criminal Justice 35, 433-451.

Kelling, G. (1992). Measuring what matters: A new way of thinking about crime and public order. City Journal (Spring): 21-33.

Kelling, George L., \& Catherine M. Coles. (1996). Fixing broken windows. New York: Free Press.

Kilkelly, U. (2008) Youth justice and children's rights: measuring compliance with international standards. Youth Justice: An International Journal 8 (3), 187 e 192.

Latimer, J., \& Kleinknecht, S. (2000). The effects of restorative justice programming: A review of the empirical research. Ottawa, Ontario: 
Department of Justice Canada, Research and Statistics Division.

Majee, W. \& Hoyt, A. (2011) Cooperatives and Community Development: A Perspective on the Use of Cooperatives in Development, Journal of Community Practice, 19:1, 48-61.

McGarrell, E. (2001). Restorative justice conferences as an early response to young offenders (NCJ 187769).Washington, DC: U.S. Department of Justice, Office of Juvenile Justice and Delinquency Prevention.

Li, S. T., Nussbaum, K. M., \& Richards, M. H. (2007). Risk and protective factors for urban African-American youth. American Journal of Community Psychology, 39, 21-35.

Marshall, T. (1999). Restorative Justice: An Overview. Home Office. Research Development and Statistics Directorate.

McDonald, J. \& Moore, D. (2001). Community Conferencing as a Special Case of Conflict Transformation in Strang, H. and Braithwaite, J. (eds.) Restorative Justice and Civil Society. Cambridge: Cambridge University Press.

Miers, D. (2001). An International Review of Restorative Justice, Crime Reduction Research Series, Paper 10. London: Home Office.

Miers, D., Maguire, M., Goldie, S., Sharpe, K., Hale, C., Netten, A., Uglow, S., Doolin,K., Hallam, A., Enterkin J. \& Newburn, T. (2001). An Exploratory Evaluation of Restorative Justice Schemes, Crime Reduction Research Series, Paper 9. London: Home Office.

Miller, J. (1998). Last One over the Wall, second ed. Ohio State University Press, Columbus.

Myers D. L. (2008). From the Editor: Accountability in Juvenile Justice: Policy and Research. Criminal Justice Policy Review September 2008 19: 255-263.

Muncie, J. (2005). The globalization of crime control e the case of youth and juvenile justice: neo-liberalism, policy convergence and international conventions. Theoretical Criminology 9 (1), 35-64.

Muncie, J. (2008). The punitive turn in juvenile justice: cultures of control and rights compliance in western Europe and the USA. Youth Justice: An International Journal 8 (2), 107-121.

Muncie, J. (2009). Youth and Crime, third ed. Sage, London.

Muncie, J. (2010). The United Nations, children's rights and juvenile justice. In: Taylor, W., Earle, R., Hester, R. (Eds.), Youth Justice Handbook: Theory, Policy and Practice. Willan, Cullompton.

Muncie, J., \& Goldson, B. (2006). States of transition: convergence and divergence in international youth justice. In: Muncie, J., Goldson, B. (Eds.), Comparative Youth Justice: Critical Issues. Sage, London.

Nowak, A. (2009).Mediation as an alternative form of the juridical proceeding toward juvenile delinquents. The new educational review, vol. 19, 3-4, 209-218.

Penn, H. (2009). Global inequalities. In: Goldson, B., Muncie, J. (Eds.), Youth Crime and Juvenile Justice. Children's Rights and State Responsibilities, vol. 3. Sage, London.

Philippi S.W., Cocozza, J., \& DePrato, D.K. (2013). Advancing Evidence-Based Practices for Juvenile Justice Reform Through Community Development. Journal of Community Practice, Vol. 21, 4, 434-450.

Pinheiro, P.S. (2005). Opening remarks from Paulo Sergio Pinheiro. In: NGO Advisory Panel for the United Nations Secretary-General's Study on Violence Against Children Violence Against Children in Conflict with the Law: A Thematic Consultation. United Nations, Geneva.

Pinheiro, P.S. (2006). World Report on Violence against Children. United Nations, Geneva.

Pranis, K. (1998). Engaging the community in restorative justice (Prepared for the Balanced and Restorative Justice (BARJ Project). Washington, DC: U.S. Department of Justice, Office of Juvenile Justice and Delinquency Prevention/Ft. Lauderdale: Florida Atlantic University/St. Paul: University of Minnesota.

Pratt, J. (2008). Scandinavian exceptionalism in an era of penal excess: part I: the nature and roots of Scandinavian exceptionalism. British Journal of Criminology 48 (2), 119-137.

Presidential Decree 448/88 (1988). Codice processo penale minorile - D.P.R. 448/1988. (G. U. n. 250 del 24 ottobre 1988, S.O.)

Pullmann, M., Kerbs, J., Koroloff, N., Veach-White, E., Gaylor, R., \& Sieler, D. (2006). Juvenile offenders with mental health needs: Reducing recidivism using wraparound. Crime \& Delinquency, 52(3), 375.

Raudenbush, S., \& Bryk, A. (2002). Hierarchical linear models: Applications and data analysis methods. Thousand Oaks, CA: Sage.

Robertson, L. M., Bates, M. P., Wood, M., Rosenblatt, J. A., Furlong, M. J., Casas, J. M., et al. (1998).

Educational placements of students with emotional and behavioral disorders served by probation, mental health, public health, and social services. Psychology in the Schools, 35, 333-345.

Rodriguez, N. (2005). Restorative justice, communities, and delinquency: Whom do we reintegrate? Criminology and Public Policy, 4(1), 103-130.

Rodriguez N. (2007). Restorative Justice at Work: Examining the Impact of Restorative Justice Resolutions on Juvenile Recidivism. Crime \& Delinquency, vol. 53, no. 3, 355-379.

Rottman, D. B. (1996). Community courts: Prospects and limits. National Institute of Justice Journal 231:46-51.

Save the Children UK (2007). The Small Hands of Slavery. Save the Children UK, London.

Sherman, L. W., Gottfredson, D., MacKenzie, D., Eck, J., Reuter, p. \& Bushway, S. (1997). Preventing crime: What works, what doesn't, what's promising: A report to the United States Congress. Research Report, NCJ 165366. Washington, D.C.: U.S. Department of Justice, National Institute of Justice.

Sprott, J. B., Jenkins, J. M., \& Doob, A. N. (2005). The importance of school: Protecting at-risk youth from early offending. Youth Violence and Juvenile Justice, 3, 59-77.

Taylor, R. B. \& Harrell, A.V. (1996). Physical environment and crime. Research Report, NCJ 157311. Washington, D.C.: U.S. Department of Justice, National Institute of Justice. 
Umbreit M. S. (1995). Holding Juvenile Offenders Accountable: A Restorative Justice Perspective. Juvenile and Family Court Journal, Volume: 46, Issue:2, Dated:(Spring 1995), Pages: 31-42.

Unicef (2010). The Children Left behind: a League Table of Inequality in Child Well-being in the World's Rich Countries. Innocenti Report Card 9. UNICEF Innocenti Research Centre, Florence.

United Nations General Assembly (1985). United Nations Standard Minimum Rules for the Administration of Juvenile Justice. United Nations, New York.

United Nations General Assembly (1989). United Nations Convention on the Rights of the Child. United Nations, New York.

United Nations General Assembly (1990a). United Nations Guidelines for the Prevention of Juvenile Delinquency. United Nations, New York.

United Nations General Assembly (1990b). United Nations Rules for the Protection of Juveniles Deprived of Their Liberty. United Nations, New York.

United Nations (2002). ECOSOC Resolution 2002/12: Basic Principles on the Use of Restorative Justice Programmes in Criminal Matters. United Nations, New York.

United Nations (2005). United Nations A/Conf.203/1: Eleventh United Nations Congress on Crime Prevention and Criminal Justice, Bangkok 18e25 April. United Nations, New York.

United Nations Committee on the Rights of the Child (2001). Consideration of Reports Submitted by States Parties under Article 44 of the Convention: Concluding Observations Portugal,

CRC/C/15/Add.162. Office of the High Commissioner for Human Rights, Geneva. United Nations Committee on the Rights of the Child (2007). General Comment No. 10: Children's

Rights in Juvenile Justice, Forty-fourth Session, 15 January-2, February. Office of the High Commissioner for Human Rights, Geneva.

United Nations Committee on the Rights of the Child (2008). Consideration of Reports Submitted by States Parties under Article 44 of the Convention: United Kingdom of Great Britain and Northern Ireland, CRC/C/GBR/CO/4. Office of the High Commissioner for Human Rights, Geneva.

United Nations Committee on the Rights of the Child (2010). Consideration of Reports Submitted by States Parties under Article 44 of the Convention: Japan CRC/C/JPN/CO/3. Office of the High Commissioner for Human Rights, Geneva.

Wacquant, L. (2009a). Punishing the Poor: The Neo-Liberal Government of Social Insecurity. Duke University Press, Durham, NC.

Wacquant, L. (2009b). Prisons of Poverty. University of Minnesota Press, Minneapolis.

WalgraveL. (1995). Restorative Justice for Juveniles: Just a Technique or a Fully Fledged Alternative? Howard Journal of Criminal Justice, Volume:34, Issue:3, Dated:(August 1995), Pages:228-249.

Walgrave, L. (1998). Restorative Justice for Juveniles: Potentialities, Risks and Problems. Leuven University Press.

Walgrave, L. (2008). Restorative Justice, Self-interest and Responsible Citizenship. Willan Publishing, UK, 2008.

Walker, H., Horner, R. H., Sugai, G., Bullis, M., Sprague, J. R., Bricker, D., et al. (1996). Integrated approaches to preventing antisocial behavior patterns among school-age children and youth. Journal of Emotional and Behavioral Disorders, 4, 194-209.

Winterdyk J. (1997). Juvenile justice systems: international perspectives. Canadian Scholars Press.

Winterdyk J. (2002). Juvenile Justice System: international perspectives. Canadian Scholars Press. 